Those taking part, about 60, were representatives from the Jordan National Red Crescent Society and from various government ministries in Jordan (Health, Foreign Affairs, Information and Education) and members of the armed forces and civil defence as well as delegates of the National Red Crescent Societies of the following countries: Bahrain, Djibouti, Iraq, Kuwait, Libya, Saudi Arabia, the Sudan, United Arab Emirates and the Yemen Arab Republic and those of the "Palestinian Red Crescent" and of the "Eritrean Red Crescent".

The seminar's chairmen were Dr. Ahmad Abu-Gura, President of the Jordan National Red Crescent Society and Chairman of the Standing Commission of the Red Cross and Red Crescent, and Mr. Abdel Ghani Ashi, Secretary-General of the General Secretariat of Arab Red Crescent and Red Cross Societies.

The lecturers were all professors of law who tailored their talks remarkably well to the audience, whom they were able to convince. Prominent among the speakers were Dr. Mohammad Aziz Shukri, from the University of Damascus, and Professors Salah el Din Amer and Said Daqqaq, both Egyptian, with whom fruitful links were established.

The work of the seminar, which was aimed both at the Red Crescent and governments, proved to be of a high standard and particularly emphasized the importance of dissemination:

\title{
FIFTH AFRICAN REGIONAL SEMINAR ON INTERNATIONAL HUMANITARIAN LAW
}

For the fifth time, the now traditional African regional seminar on international humanitarian law was held at Yaoundé, from 26 November to 4 December 1986. It was organized by the Henry Dunant Institute and the Institute of International Relations of Cameroon (IIRC), with the collaboration of the ICRC.

This seminar, the purpose of which was to examine the multiple aspects and recent developments of international humanitarian law, was attended by 78 participants from 28 African nations, including diplomats, jurists, university professors, journalists, members of the armed forces and of the National Red Cross and Red Crescent Societies. About thirty IIRC students were also present.

The opening and closing meetings of the seminar were honoured by the presence of the Minister of Foreign Affairs of 
Cameroon, Mr. Eteki Mboumoua and that of the President of the Cameroon Red Cross, Mr. S. Pierre Tchoungui.

The ICRC was represented by Mr. Chappuis, Delegate-General for Africa, Mr. Rigopoulo, Regional Delegate based in Lagos, and Mr. Siegenthaler, legal delegate, Operational Activities. The Henry Dunant Institute had delegated Mr. Toman, Interim Director.

The subjects dealt with were successively introduced by sixteen speakers, most of them African. The working meetings enabled African representatives from various nations to discuss problems of humanitarian law, compare the applications of that law in different countries and rediscover the universal character of the principles of humanitarian law, many of which are echoed by African traditions. In this respect, the seminar recommended that a global study be undertaken of African humanitarian traditions and of their interaction with international humanitarian law "as a means of promoting a better understanding and acceptance of humanitarian law by African Societies, States and Peoples".

The seminar, conducted in English and French, took place in excellent conditions and received special attention from the local press. It was the subject of radio and television broadcasts, including interviews with various speakers and participants.

The work of the seminar, the high level of which was repeatedly stressed, once again benefited from a wide range of skills displayed by participants from diverse backgrounds and representing a variety of disciplines. Such diversity fosters fruitful exchanges of views and valuable contacts, while at the same time bringing to the work of this type of seminar new ideas and possibilities depending on the outlook, experience and main concerns of each participant.

Participants were unanimous in expressing the desire to see these seminars continue on a regular basis.

\section{A great promoter of Henry Dunant's message is no more}

Mr. Jakob Haug, founder of the Henry Dunant Museum in Heiden, has passed away at the age of 87 . With him disappears one of the most engaging figures in the twentieth-century history of the 